\title{
Comparative Cost Analysis of Cervical Cancer Screening Programme Based on Molecular Detection of Hpv In Spain
}

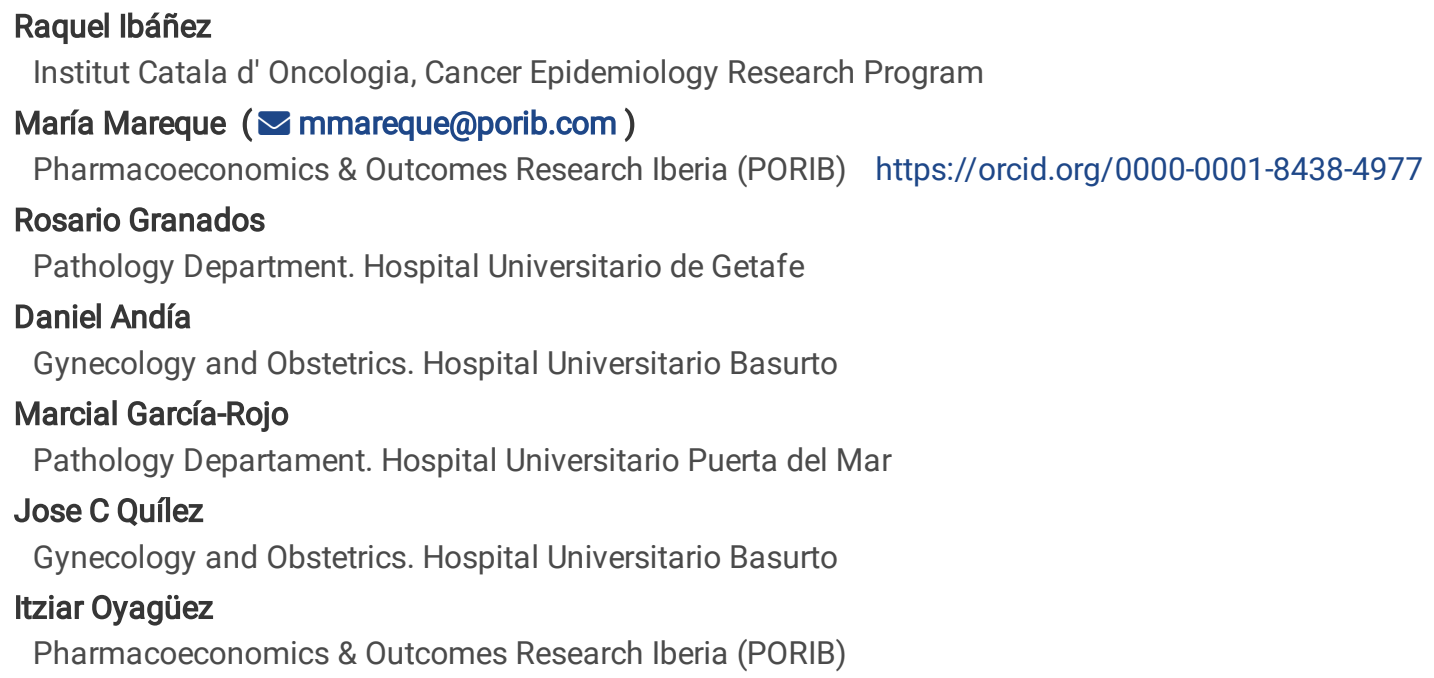

\section{Research article}

Keywords: Cervical cancer screening, human papilloma virus, Aptima HPV assay, cost analysis

Posted Date: July 21st, 2020

DOI: https://doi.org/10.21203/rs.3.rs-42442/v1

License: (c) (i) This work is licensed under a Creative Commons Attribution 4.0 International License. Read Full License

Version of Record: A version of this preprint was published at BMC Women's Health on April 26th, 2021. See the published version at https://doi.org/10.1186/s12905-021-01310-8. 


\section{Abstract \\ Background}

HPV cervical cancer screening (CCS) must use validated HPV tests based on the molecular detection of either viral mRNA (Aptima HPV Assay - AHPV) or DNA. AHPV has demonstrated the same cross-sectional and longitudinal sensitivity for the detection of HSIL/CIN2 + lesions but with greater specificity than HPV-DNA tests. The study aimed to estimate the total costs of a CCS with a primary HPV test based on the detection of mRNA compared to DNA in women aged 35-65 years for the National Health System.

\section{Methods}

A decision-tree-based model to estimate the cost of the CCS until the first colposcopy was designed based on Spanish CCS guidelines. The total cost $(€, 2019)$ for CCS with AHPV or DNA tests (HC2 and Cobas) was calculated, including HPV test, liquid-based cytology (LBC) and colposcopy, for a population of 7,263,529 women aged $35-65$ years (assuming $70 \%$ coverage). Clinical inputs derived from a literature review were validated by a multidisciplinary expert panel. Data from head-to-head studies between different HPV tests were selected. The HPV prevalence used in women aged $35-64$ was $7.5 \%$ for AHPV, $11.5 \%$ for HC2 and $12.4 \%$ for Cobas.

\section{Results}

The use of AHPV avoided 151,699 (-47\%) and 151,165 (-47\%) colposcopies and 290,541 (-35\%) and 355,913 (-40\%) LBC vs HC2 and Cobas, respectively; and allows saving $€-39,839,711$ vs HC2 and $€-41,866,613$ vs Cobas.

\section{Conclusions}

Assuming that $70 \%$ of women from 35-65 years attend the CCS programme, the cost of screening up to the first colposcopy using AHPV would provide cost savings of up to €41.9 million vs DNA tests in Spain.

\section{Background}

Cervical cancer is the fourth most frequent malignant tumour in the world among women, with at least 500,000 new cases diagnosed every year and a world standardized incidence of 13.1 per $10^{5}$ women in 2018. This disease is also the fourth leading cause of cancer death worldwide. Globocan data for 2018 estimate that approximately 311,000 deaths occurred due to cervical cancer among women with a world standardized mortality of 6.9 per $10^{5}$ women. Approximately $85 \%$ of these deaths occur in developing countries [.

In Spain, the world standardized incidence of cervical cancer is $5.2 \times 10^{5}$ women, one of the countries with the lowest incidence of this cancer in the world ${ }^{1}$. The mortality associated with this disease is 1.7 cases per 100,000 women per year [1]. In absolute numbers, it represents approximately 1,900 cervical cancer diagnoses and 825 deaths per year [1].

The aetiological cause of cervical cancer is infection with oncogenic types of human papillomavirus (HPV) []. HPV infection is sexually transmitted, infecting the anogenital and oral areas. It is very common among the sexually active population, reaching the highest prevalence at the beginning of sexual intercourse, with a marked decrease after 30 years of age [].

Currently, the development of HPV vaccines and the updating of screening protocols, by replacing cytology for the HPV test as a primary screening, have made cervical cancer a preventable disease [. In fact, the World Health Organization defined 2018 as the beginning year of cervical cancer elimination as a public health problem in the world, establishing the objective of reducing its incidence below 4 cases per $10^{5}$ women per year $\square$.

For more than fifty years, cervical cancer screening (CCS) has been based on the analysis of conventional or liquid-based cervical cytology with the aim of detecting high grade cervical intraepithelial neoplasia or worse (HSIL/CIN2+) lesions to treat them and prevent their progression to cervical cancer [. However, with the development of HPV tests, there is extensive scientific evidence demonstrating its superiority as a primary screening test compared to cytology [6,]. HPV detection offers an increase in sensitivity of $30-40 \%$ for the detection of HSIL/CIN2 + and a loss of 3-5\% of specificity [9]. Clinical trials conducted in European countries, for which there are follow-up data of at least two rounds of screening, have shown that the HPV as a primary test, starting at age 30 , offers a $60-70 \%$ increased 
protection against cervical cancer as compared to cytology [. These studies also showed that screening with an HPV test every 5 years offers better protection against cervical cancer than screening with cytology every 3 years [10].

Based on accumulated scientific evidence, the main scientific societies involved in the prevention of this cancer have updated the guidelines [6], recommending the implementation of a population-based screening programme and the introduction of HPV screening with a preference over a cytology screening strategy in women from the age of 30. On the other hand, it has also been internationally agreed that for its use in screening, only clinically validated HPV detection techniques can be used [].

The National Health Ministry in Spain recommends that CCS be based on European and National practice guidelines, using two primary tests for the detection of cervical cancer: 1) liquid-base cytology (LBC) every 3 years for women from 25-34 years old with an HPV test as triage for women with atypical squamous cells of unknown significance (ASC-US) and colposcopy for the remaining abnormal cytological results, and 2) HPV primary testing every 5 years in women aged 35 to 65 years with cytology triage of HPV-positive women [6,m].

There are several validated HPV assays as primary screening tests based on the molecular detection of either HPV mRNA or DNA. According to clinical evidence, the Aptima HPV Assay (AHPV), used as a primary screening test, has shown to have the same crosssectional and longitudinal sensitivity but higher specificity than DNA HPV tests for detecting HSIL/CIN2+ [,m]. Due to their higher specificity, this test can reduce false-positive results, avoiding unneeded anxiety, overdiagnosis and overtreatment and therefore saving costs [].

The estimation of the economic benefit resulting from the increased test specificity applied to a CCS programme has not yet been reported. The objective of the present study was to estimate the total costs from the outset up to the first colposcopy of a population-based CCS with a primary HPV test based on the molecular detection of mRNA versus DNA in Spain.

\section{Methods}

\section{Model structure}

A cost-analysis model was developed with Microsoft Excel ${ }^{\circledR}$. The design and structure of the model as well as the parameters needed for the development of the analysis were defined by a multidisciplinary expert panel composed of 2 gynaecologists, 3 pathologists, 1 epidemiologist and 3 health economics specialists. A structured questionnaire that included the values identified in the scientific published literature was developed and filled by the expert panel. Subsequently, an expert meeting was carried out to validate and agree upon all the values used in the analysis.

\section{Modelling}

Two scenarios were considered to estimate the costs associated with the CCS for all Spanish populations covered by the screening programme, including the first colposcopy. The initial analysis was performed in women 35-65 years old, where the primary screening was performed with HPV testing (base case). The alternative analysis considered the subgroup of women 25-34, where the primary screening was carried out with LBC (alternative case).

A decision tree model was designed for the two scenarios considering the recommendations of the current screening guidelines available in Spain [13] (Figure 1).

The analysis started with the cohorts accessing the CCS. Along the simulation, women were transitioning between the different nodes according to the probability of event occurrence. For this economic analysis, the model stops after performance of the colposcopy in those women requiring it. The decision tree nodes represented events derived from the findings of their HPV, LBC, colposcopy, and biopsy results.

Furthermore, LBC was considered in the analysis for sample collection, allowing the reflex test to be performed in both scenarios, thus avoiding the collection of a new sample.

The probabilities needed were obtained from the available scientific epidemiological publications and clinical trials of HPV testing.

\section{Study population}

Following the recommendations of the Spanish guidelines for CCS [13,[i]], the primary HPV CCS included the Spanish population of women aged 35-65 years (base case), and the cytological screening included women aged 25-34 (alternative case).

The number of the different populations was obtained from the National Institute of Statistics for 2018 [[ii]]. It was assumed that all women in the target population would be invited to participate in the CCS. In accordance with the AFRODITA study [[iii]], it was considered 
that $70 \%$ of invited women would attend their screening appointment. Therefore, the final population assessed in the model was 7,263,529 Spanish women from ages 35 to 65 and 1,947,925 women from ages 25 to 34, assuming that all of them were asymptomatic.

\section{HPV testing}

Based on the expert panel recommendations, three molecular detection HPV tests were considered in the analysis: one HPV mRNA test [Aptima human papillomavirus assay (Hologic, Inc., San Diego, USA)] and two HPV DNA tests [Hybrid Capture 2 high-risk HPV DNA test (Qiagen, Gaithersburg, MD, USA) and Cobas 4800 HPV test (Roche Molecular Diagnostics, Pleasanton, CA, USA)].

The Hybrid Capture 2 (HC2) high-risk HPV DNA test is considered the gold standard of HPV assays, as its performance was validated in many randomized controlled trials. HC2 collectively detects 13 high-risk (hr) HPV genotypes $(16,18,31,33,35,39,45,51,52,56,58,59$ and 68). Aptima human papillomavirus (AHPV) is an in vitro nucleic acid amplification test for the qualitative detection of E6/E7 viral transcript mRNA from $14 \mathrm{hr} \mathrm{HPV} \mathrm{types} \mathrm{in} \mathrm{cervical} \mathrm{smear} \mathrm{samples.} \mathrm{The} \mathrm{hr} \mathrm{HPV} \mathrm{types} \mathrm{detected} \mathrm{by} \mathrm{the} \mathrm{assay} \mathrm{are} \mathrm{16,} \mathrm{18,} \mathrm{31,} \mathrm{33,} \mathrm{35,} \mathrm{39,} \mathrm{45,} \mathrm{51,} \mathrm{52,} \mathrm{56,} \mathrm{58,}$ 59, 66, and 68. Likewise, the Cobas 4800 test detects the same $14 \mathrm{hr}$ HPV genotypes as the AHPV assay. However, while the Roche assay detects hr HPV DNA, the Aptima assay detects hr HPV oncogenic mRNA expression and is designed to be more specific in identifying clinically significant hr HPV infections that are likely to lead to high-grade squamous dysplasia and neoplasia.

In the model, two different scenarios were compared: scenario 1, AHPV versus HC2; and scenario 2, AHPV versus Cobas 4800. Although some of these HPV tests give, in addition to the overall result for all included hr HPV types (positive/negative), the partial result for HPV 16 and HPV 18. This partial result was not taken into account in this study. The current analysis only considers the overall result for all three HPV tests.

\section{Clinical data}

A literature review was conducted in Medline through PubMed to identify publications regarding the clinical evidence in this field and to extract the probabilities needed. The search strategy is shown in Appendix 1 and Appendix 2.

An initial selection of 1,408 localized references was performed by reading the title and abstract. Subsequently, 80 studies were considered relevant for this analysis and were selected and reviewed in full text. The probabilities of the different clinical data included in the analysis were obtained from the most relevant clinical studies. Among all publications, those studies that provided data from direct comparisons between the selected HPV tests were prioritized.

In this sense, the prevalence of HPV for base case was obtained from a transversal head-to-head study about HPV tests in a screening population [[iv]]. This study showed rates of $7.5 \%, 11.50 \%$ and $12.40 \%$ for AHPV, HC2 and Cobas 4800 , respectively (Table 1).

Regarding the proportion of women with abnormal LBC after a positive HPV test result, several studies were identified [[v],[vi],[vii]]. These transition probabilities are shown in Table 1.

For the alternative case, the prevalence of women with abnormal LBC was 6.5\% [25]. Other transition probabilities for the different nodes considered in the decision tree model for this subgroup of women from 25-34 years are shown in Table 1.

\section{Costs}

The analysis was carried out from the perspective of the Spanish National Health System (NHS); therefore, only direct health care costs were included, comprising HPV and diagnostic test costs (LBC, colposcopy, and biopsy costs). Figure 1 describes when and which of each of the health care resources were considered.

Unitary costs were obtained from the available scientific literature or regional public information [21,[viii],[ix]] and from a national database of health care costs [[x]]. All costs included in the model were expressed in euros for 2019, updating the costs obtained from the literature based on the Spanish general consumer price index, if needed [[xi]].

Table 1 shows the unitary costs of the direct health care resources included in the model.

\section{Sensitivity analysis}

Several univariate sensitivity analyses (SAs) were performed to incorporate the uncertainty into the analysis and to observe the effect of these modifications on the results. The following parameters were varied individually: 1) One-way SA was carried out considering a possible reduction in the women from 35-65 years of age who would attend their screening appointment, assuming that $36.3 \%$ of these 
women attended the CCS in private practice [23] and that $44.6 \%$ of first screening attendees used the public sector. In all cases, an organized CCS with an individual invitation to the target women was considered. 2) To represent a range for the most plausible results of the clinical data regarding women from 35-65 years with a positive HPV result, a univariate SA was performed with the studies showing the largest [16,[xii]] and smallest [[xiii],[xiv]] differences between the test considered in the analysis. 3) Finally, primary LBC, colposcopy and biopsy unitary costs were modified considering the alternative values identified in the literature $[21,[x v]]$. An additional scenario was performed with the upper and lower values of these health resources, obtained by applying the standard deviation (SD) to the mean value (Table 1).

[i] López de Argumedo González de Durana M, Bayón Yusta JC, Mateos del Pino M. Impacto de la implantación de un programa de cribado poblacional de cáncer de cérvix, siguiendo las recomendaciones europeas (prueba/intervalo) en relación a la situación actual. Ministerio de Sanidad, Servicios Sociales e Igualdad. Servicio de Evaluación de Tecnologías Sanitarias del País Vasco; 2016. Informes de Evaluación de Tecnologías Sanitarias: OSTEBA.

[ii] Instituto Nacional de Estadística. Proyecciones de población 2016-2066. Población residente en España a 1 de enero, por sexo, edad y año. En: INEbase [Internet]. Madrid: Instituto Nacional de Estadística; 2018. Available at: www.ine.es

[iii] Puig-Tintoré LM, Castellsagué X, Torné A, et al. Coverage and factors associated with cervical cancer screening: results from the AFRODITA study: a population-based survey in Spain. J Low Genit Tract Dis. 2008;12(2):82-9.

[iv] Cuzick J, Cadman L, Mesher D, et al. Comparing the performance of six human papillomavirus tests in a screening population. Br J Cancer. 2013;108(4):908-13.

[v] Granados R, Tellez-Safina H, Solis I, et al. Cervical cancer screening cotesting with cytology and MRNA HPV E6/E7 yields high rates of CIN2+ lesions in young women. Diagn Cytopathol. 2017;45(12):1065-1072.

[vi] Passamonti B, Gustinucci D, Giorgi Rossi P, et al. Cervical human papilloma virus (HPV) DNA primary screening test: Results of a population-based screening programme in central Italy. J Med Screen. 2017;24(3):153-162.

[vii] Gage JC, Katki HA, Schiffman M, et al. Age-stratified 5-year risks of cervical precancer among women with enrollment and newly detected HPV infection. Int J Cancer. 2015;136(7):1665-71.

[viii] Orly de Labry Lima A, Epstein D, García Mochón L, Ruiz Aragón J, Espín Balbino J. Análisis de coste-efectividad de la prueba de citología cervicovaginal. Prog Obstet Ginecol. 2012;55(7):304-11.

[ix] Resolución de la Dirección Gerencia del Hospital Universitario de Getafe, por la que se adjudica el contrato de suministros de citología líquida para el Hospital Universitario de Getafe. Hospital Universitario de Getafe; 2018.

[x] Oblikue Consulting. Base de datos de costes sanitarios eSalud [eSalud Health Cost database] [Internet]. Barcelona: Oblikue Consulting; 2019. Available at: http://www.oblikue.com/bddcostes/

[xi] Instituto Nacional de Estadística. Índices de Precios al Consumo [consulted January 2019]. Available at: http://www.ine.es/varipc/

[xii] Rebolj M, Preisler S, Ejegod DM, et al. Disagreement between human papillomavirus assays: an unexpected challenge for the choice of an assay in primary cervical screening. PLoS One. 2014;9(1):e86835.

[xiii] Cook DA, Smith LW, Law J, et al. Aptima HPV Assay versus Hybrid Capture(®) 2 HPV test for primary cervical cancer screening in the HPV FOCAL trial. J Clin Virol. 2017;87:23-29.

[xiv] White C, Reynolds S, Naik P, et al. HPV Primary Screening Pilot Study: molecular testing of potential triage strategies for HPV-positive women. Oral Abstract presented at The British Society for Colposcopy and Cervical Pathology, 2017 May 3-5, Cardiff, Wales.

[xv] Diaz M, de Sanjose S, Ortendahl J, et al. Cost-effectiveness of human papillomavirus vaccination and screening in Spain. Eur J Cancer. 2012;46(16):3973-85.

\section{Results}

Assuming that $70 \%$ of women aged $35-65$ years would attend the CCS, when AHPV was used instead of HC2 or Cobas 4800 as the primary test, there was a reduction of 290,541 (35\% decrease) and 355,913 LBC samples ( $40 \%$ decrease), respectively. Furthermore, the use of

Page 5/14 
AHPV avoided 151,699 (47\% reduction) colposcopies compared to HC2 and 151,165 (47\% reduction) compared to Cobas 4800 (Table 2 ).

The total cost of CCS, including the performance of the first colposcopy, in women aged 35-65 years was €282,747,877 with AHPV, $€ 322,587,588$ with $\mathrm{HC} 2$ and $€ 324,614,490$ with Cobas 4800 . Therefore, the savings from using AHPV versus a DNA HPV test range between 39.8 and 41.9 million euros (Table 2).

Including the activity of CCS in women aged 25-34 years and considering the costs up to the first colposcopy with a 70\% coverage, the use of AHPV provided a total reduction of 158,105 colposcopies and 290,541 LBC samples compared to HC2 and 154,193 colposcopies and 355,913 LBC samples versus Cobas 4800. Therefore, the total cost up to, and including the first colposcopy after the CCS programme implementation with AHPV saves up to $€-41,121,564$ when compared to HC2 and $€-42,472,579$ versus Cobas 4800 (Figure 2 ).

\section{Sensitivity analysis}

The results of the different univariate SAs are shown in Table 2. Regarding the deterministic SA, AHPV is the least costly option and reduces the number of tests in all analysed scenarios, confirming the base case results.

The one-way SA that had the highest influence on the results was considering alternative published evidence of the proportion of women with a positive HPV test result [33,34], followed by the variation in cost based on literature evidence [21].

When the studies with the greatest differences in HPV positivity were used, AHPV saves up to $€-53,970,312$ compared to HC2 and $€-78,647,307$ compared to Cobas 4800. On the other hand, if we calculated cost savings based on the studies with the smallest differences in positive HPV results, AHPV showed savings of up to $€-17,232,932$ and $€-21,935,110$ when compared to HC2 and to Cobas 4800, respectively.

Regarding the reduction in women from 35-65 years of age who would attend their screening appointment in the public sector ( $n=4,626,868$ women), the use of AHPV provided a cost-saving of $€-25,37,896$ versus HC2 and $€-26,669,032$ versus Cobas 4800 .

Based on the decrease in primary LBC, colposcopy and biopsy costs, when the upper value of the cost reported in the literature was applied, using AHPV would save up to $€-49,733,682$ compared to HC2 and $€-52,257,582$ compared to Cobas 4800 (Table 2). The savings are $€-22,865,273$ versus $\mathrm{HC} 2$ and $€-23,342,515$ versus Cobas 4800 when using the lower value of the reported cost (Table 2).

Regarding the SA calculated with the upper and the lower values obtained by applying the standard deviation (SD) to the mean value of primary LBC, colposcopy and biopsy unitary costs, the savings oscillate between $€-35,899,792$ and $€-43,779,630$ for AHPV versus HC2 and between $€-37,135,197$ and $€-46,598,028$ for AHPV versus Cobas 4800 .

\section{Discussion}

Several economic analyses have assessed the cost of a publicly funded CCS in Spain [21,35,], all oriented to evaluate the most efficient way to implement a primary HPV screening programme in Spain. However, none of these studies evaluated the economic impact of the use of mRNA or DNA tests in the CCS programme. The present study is the first cost-analysis assessing the impact of different HPV tests on overall CCS programme cost by comparing an mRNA test (AHPV) with an HPV DNA test (HC2 or Cobas 4800) in Spain.

The introduction of HPV as primary tests in CCS has the advantage of being more sensitive for the detection of HSIL/CIN2 + but they are substantially less specific than cytology [9]. HPV positive results require triaging to differentiate those women at increased risk of having or developing HSIL/CIN2 + lesions from those at lower risk with potentially transient HPV infections. HPV tests have shown similar clinical sensitivity for the detection of HSIL/CIN2 + with varying overall positivity and clinical specificity. Several studies have shown that AHPV is suitable for use as a primary screening test for CCS [], having a similar longitudinal sensitivity and negative predictive value as HPV-DNAbased assays for the detection of HSIL/CIN2 + but with significantly increased specificity [19,33,37, ]. The reason is that AHPV detects the expression of HPV E6/7 mRNA, reducing the detection of transient infections that are less likely to lead to the development of HSIL/CIN2+.

The results of this study showed that the use of AHPV can be associated with a reduction in additional LBC triage tests and follow-up procedures, measured by number of colposcopies, with a consequent reduction in the total cost of CCS programmes in 35-65-year-old Spanish women as observed in the alternative scenario. These cost savings are a direct result of the increased specificity reducing the number of women referred for further management.

Similar economic studies have been performed in other countries. In 2012, Sauter JL et al. (2014) reported a 21\% reduction in colposcopy referrals in the 12 months following the change from HC2 to AHPV in women with an ASC-US diagnosis [17]. In our analysis, this reduction 
is even larger with up to $47 \%$ fewer colposcopies, due to the use of HPV as the primary screening test. Two additional US studies have evaluated the health economic impacts of utilizing AHPV compared to DNA tests, either with LBC co-testing or as primary HPV testing []. These studies similarly report that mRNA assays provide cost savings versus DNA testing. Finally, a recent analysis conducted in England suggested that the use of AHPV over DNA based testing could result in savings of up to $£ 11.3$ million ( $€ 13.8$ million) for the screening system $[$.

The present model has some limitations. First, the parameters used in the analysis have been extracted from different sources. However, all variables are based on official sources or on publications with a high level of clinical evidence, and they have been validated by a multidisciplinary expert panel. The potential uncertainty associated with some of the parameters was tested in a univariate SAs. Second, the influence of the additional procedure costs performed in women with a positive HPV test result (LCB, colposcopy and biopsy) was also tested in a SA. As observed, none of these two SAs changed the conclusions of the base case results.

Another possible limitation could be related to the use of clinical data extracted from studies conducted in other countries, as no robust head-to-head comparative studies have been conducted in Spain. The literature review provided a wide variety of reports; however, a limited number of studies with direct comparisons between mRNA and DNA tests were found. Among all available studies, two of them $[17,24]$ evaluated the tests included in this analysis. For our study, these reports were selected to avoid the potential bias associated with differences in populations, methodologies and/or local patient management between different locations. The SA performed using the most plausible values for HPV-positive women (minimum and maximum differences between tests) also maintained the conclusions of the base case.

This study used an analytic model to assess the health cost after a CCS programme implementation (from the beginning of the implementation to the end of the first colposcopy) with a HPV mRNA test (AHPV) compared to an HPV DNA test (HC2 or Cobas) in women aged 35-65 years in Spain. Initially, the decision tree model was developed and designed considering the entire time horizon for a complete CCS programme based on current recommendations from national and European guidelines [6,12] and was validated and agreed upon by a multidisciplinary expert panel. Due to the lack of reliable clinical data to feed all the probabilities of the model and in order to simplify the analysis, it was decided to shorten the time horizon until the completion of the first colposcopy. The scarce available evidence suggests the need for future development of epidemiological studies that could provide more detailed data to replicate the present analysis with a longer time horizon or follow up after an abnormal test result.

Despite the limitations described above, the results of the sensitivity analysis confirm that the uncertainty associated with the parameters used in the economic analysis did not represent a significant deviation from the results obtained in the base case, showing that AHPV is the less costly option, reducing testing in all the scenarios evaluated.

\section{Conclusion}

In conclusion, assuming that 70\% of women from 35-65 years attend the population-based CCS programme in Spain, the cost of screening up to completion of the first colposcopy using AHPV could generate health cost savings up to 39.8-41.9 million euros when compared to DNA testing.

\section{Abbreviations}

AHPV

Aptima HPV Assay

ASC-US

Atypical squamous cells of unknown significance

CCS

Cervical cancer screening

$\mathrm{Hc} 2$

Hybrid Capture $2 \mathrm{HC} 2$

HSIL/CIN2+

High grade cervical intraepithelial neoplasia or worse

HPV

Human papillomavirus

LBC

Liquid-base cytology 
NHS

National Health System

SA

Sensitivity analyses

SD

Standard deviation

\section{Declarations}

Ethics approval and consent to participate: Not applicable. Ethics approval is considered unnecessary according to national regulations since it is not a study but an economic evaluation. As our work is not related to patients since it is not a study, informed consent does not apply.

Consent for publication: Not applicable

\section{Availability of data and materials:}

The datasets used and/or analysed during the current study are available from the corresponding author upon reasonable request and with permission of Hologic Spain.

\section{Competing interests:}

MM and IO are currently employed at PORIB, a consultant company specialized in economic evaluation of health interventions, which received financial support from Hologic for the development of this study. MG, DA, RI and JCQ have received honoraria from Hologic for advocacy tasks related to this project. RI received HPV tests free of charge by Roche.

\section{Funding:}

This study was funded by Hologic Spain. The funding body was involved in structure design and review of the writing of the manuscript.

\section{Authors' contributions:}

IO and MM have designed the current evaluation. MG, DA, RI, RG and JCQ validated the design of the model and parameters to be used in the model. All authors have been involved in the writing of the manuscript at draft and any revision stages and have read and approved the final manuscript.

Acknowledgements: Not applicable

\section{References}

1. Bray F, Ferlay J, Soerjomataram I, et al. Global Cancer Statistics 2018: GLOBOCAN Estimates of Incidence and Mortality Worldwide for 36 Cancers in 185 Countries. Ca Cancer J Clin. 2018;68:394-424.

2. Walboomers JM, Jacobs MV, Manos MM, et al. Human papillomavirus is a necessary cause of invasive cervical cancer worldwide. $J$ Pathol. 1999;189(1):12-9.

3. Bosch FX, Lorincz A, Muñoz N, et al. The causal relation between human papillomavirus and cervical cancer. J Clin Pathol. 2002;55(4):244-65.

4. Castellsagué X, Iftner T, Roura E, et al. Prevalence and genotype distribution of human papillomavirus infection of the cervix in Spain: the CLEOPATRE study. J Med Virol. 2012;84(6):947-56.

5. Schiffman M, Doorbar J, Wentzensen N, et al. Carcinogenic human papillomavirus infection. Nat Rev Dis Primers. 2016;2:16086.

6. Von Karsa L, Arbyn M, De Vuyst H, et al. European guidelines for quality assurance in cervical cancer screening. Summary of the supplements of HPV screening and vaccination. Papillomavirus Research. 2015;1:22-31.

7. World Health Organization. Health topics/Cervical cancer. Eliminating cervical cancer. Available at: https://www.who.int/healthtopics/cervical-cancer\#tab=tab_2

8. Anttila A, Ronco G, Clifford G, et al. Cervical cancer screening programmes and policies in 18 European countries. Br J Cancer. 2004;91(5):935-41. 
9. Koliopoulos G, Nyaga VN, Santesso N, et al. Cytology versus HPV testing for cervical cancer screening in the general population. Cochrane Database Syst Rev. 2017;8:CD008587.

10. Ronco G, Dillner J, Elfström KM, et al. Efficacy of HPV-based screening for prevention of invasive cervical cancer: follow-up of four European randomised controlled trials. Lancet. 2014;383(9916):524-32.

11. Arbyn M, Snijders PJ, Meijer CJ, et al. Which high-risk HPV assays fulfil criteria for use in primary cervical cancer screening? Clin Microbiol Infect. 2015;21(9):817-26.

12. Torné A, del Pino M, Cusidó M, et al. Guía de cribado del cáncer de cuello de útero en España. Rev Esp Patol. 2014;47(Supl 1):1-43.

13. Asociación Española de Patología Cervical y Colposcopia. Guías de práctica clínica en cáncer ginecológico y mamario. Prevención del cáncer de cuello de útero. Oncoguía SEGO. 2014. Available at: http://www.aepcc.org/wpcontent/uploads/2016/01/AEPCC_revista02.pdf

14. Orden SCB/480/2019, de 26 de abril, por la que se modifican los anexos I, III y VI del Real Decreto 1030/2006, de 15 de septiembre, por el que se establece la cartera de servicios comunes del Sistema Nacional de Salud y el procedimiento para su actualización. Boletín Oficial del Estado de 27 de abril de 2019 [Internet]. Madrid: Agencia Estatal Boletín Oficial del Estado; 2019. Disponible en: https://www.boe.es/boe/dias/2019/04/27/pdfs/BOE-A-2019-6277.pdf

15. Rebolj M, Bonde J, Preisler S, et al. Human Papillomavirus Assays and Cytology in Primary Cervical Screening of Women Aged 30 Years and Above. PLoS One. 2016;11(1):e0147326.

16. Monsonego J, Hudgens MG, Zerat L, et al. Risk assessment and clinical impact of liquid-based cytology, oncogenic human papillomavirus (HPV) DNA and mRNA testing in primary cervical cancer screening (the FASE study). Gynecol Oncol. 2012;125(1):17580.

17. Sauter JL, Mount SL, St John TL, et al. Testing of integrated human papillomavirus mRNA decreases colposcopy referrals: could a change in human papillomavirus detection methodology lead to more cost-effective patient care? Acta Cytol. 2014;58(2):162-6.

18. Iftner T, Becker S, Neis KJ, et al. Head-to-Head Comparison of the RNA-Based Aptima Human Papillomavirus (HPV) Assay and the DNA-Based Hybrid Capture 2 HPV Test in a Routine Screening Population of Women Aged 30 to 60 Years in Germany. J Clin Microbiol 2015;53(8):2509-16.

19. Iftner T, Neis KJ, Castanon A, et al. Longitudinal Clinical Performance of the RNA-Based Aptima Human Papillomavirus (AHPV) Assay in Comparison to the DNA-Based Hybrid Capture 2 HPV Test in Two Consecutive Screening Rounds with a 6-Year Interval in Germany. J Clin Microbiol. 2019;57(1). pii: e01177-18.

20. Benevole M, Vocaturo A, Caraceni D, et al. Sensitivity, specificity, and clinical value of human papillomavirus (HPV) E6/E7 mRNA assay as a triage test for cervical cytology and HPV DNA test. J Clin Microbiol. 2011;49(7):2643-50.

21. López de Argumedo González de Durana M, Bayón Yusta JC, Mateos del Pino M. Impacto de la implantación de un programa de cribado poblacional de cáncer de cérvix, siguiendo las recomendaciones europeas (prueba/intervalo) en relación a la situación actual. Ministerio de Sanidad, Servicios Sociales e Igualdad. Servicio de Evaluación de Tecnologías Sanitarias del País Vasco; 2016. Informes de Evaluación de Tecnologías Sanitarias: OSTEBA.

22. Instituto Nacional de Estadística. Proyecciones de población 2016-2066. Población residente en España a 1 de enero, por sexo, edad y año. En: INEbase [Internet]. Madrid: Instituto Nacional de Estadística; 2018. Available at: www.ine.es

23. Puig-Tintoré LM, Castellsagué $X$, Torné $A$, et al. Coverage and factors associated with cervical cancer screening: results from the AFRODITA study: a population-based survey in Spain. J Low Genit Tract Dis. 2008;12(2):82-9.

24. Cuzick J, Cadman L, Mesher D, et al. Comparing the performance of six human papillomavirus tests in a screening population. Br $\mathrm{J}$ Cancer. 2013;108(4):908-13.

25. Granados R, Tellez-Safina H, Solis I, et al. Cervical cancer screening cotesting with cytology and MRNA HPV E6/E7 yields high rates of CIN2+ lesions in young women. Diagn Cytopathol. 2017;45(12):1065-1072.

26. Passamonti B, Gustinucci D, Giorgi Rossi P, et al. Cervical human papilloma virus (HPV) DNA primary screening test: Results of a population-based screening programme in central Italy. J Med Screen. 2017;24(3):153-162.

27. Gage JC, Katki HA, Schiffman M, et al. Age-stratified 5-year risks of cervical precancer among women with enrollment and newly detected HPV infection. Int J Cancer. 2015;136(7):1665-71.

28. Orly de Labry Lima A, Epstein D, García Mochón L, Ruiz Aragón J, Espín Balbino J. Análisis de coste-efectividad de la prueba de citología cervicovaginal. Prog Obstet Ginecol. 2012;55(7):304-11.

29. Resolución de la Dirección Gerencia del Hospital Universitario de Getafe, por la que se adjudica el contrato de suministros de citología líquida para el Hospital Universitario de Getafe. Hospital Universitario de Getafe; 2018. 
30. Oblikue Consulting. Base de datos de costes sanitarios eSalud [eSalud Health Cost database] [Internet]. Barcelona: Oblikue Consulting; 2019. Available at: http://www.oblikue.com/bddcostes/

31. Instituto Nacional de Estadística. Índices de Precios al Consumo [consulted January 2019]. Available at: http://www.ine.es/varipc/

32. Rebolj M, Preisler S, Ejegod DM, et al. Disagreement between human papillomavirus assays: an unexpected challenge for the choice of an assay in primary cervical screening. PLoS One. 2014;9(1):e86835.

33. Cook DA, Smith LW, Law J, et al. Aptima HPV Assay versus Hybrid Capture(®) 2 HPV test for primary cervical cancer screening in the HPV FOCAL trial. J Clin Virol. 2017;87:23-29.

34. White C, Reynolds S, Naik P, et al. HPV Primary Screening Pilot Study: molecular testing of potential triage strategies for HPV-positive women. Oral Abstract presented at The British Society for Colposcopy and Cervical Pathology, 2017 May 3-5, Cardiff, Wales.

35. Diaz M, de Sanjose S, Ortendahl J, et al. Cost-effectiveness of human papillomavirus vaccination and screening in Spain. Eur J Cancer. 2012;46(16):3973-85.

36. García-Garrido AB, Vázquez-Rodríguez JA, Grande-González E, et al. Cobertura y costes del cribado oportunista de detección precoz del cáncer de cuello uterino en Cantabria. Gac Sanit. 2014;28(1):14-9.

37. Trapero-Bertran M, Acera Pérez A, de Sanjosé S, et al. Cost-effectiveness of strategies to increase screening coverage for cervical cancer in Spain: the CRIVERVA study. BMC Public Health. 2017;17(1):194.

38. Heideman DA, Hesselink AT, van Kemenade FJ, et al. The Aptima HPV assay fulfills the cross-sectional clinical and reproducibility criteria of international guidelines for human papillomavirus test requirements for cervical screening. J Clin Microbiol 2013;51: 3653-7.

39. Forslund O, Miriam Elfström K, Lamin H, et al. HPV-mRNA and HPV-DNA detection in samples taken up to seven years before severe dysplasia of cervix uteri. Int J Cancer. 2019;144(5):1073-81.

40. Haedicke J, Iftner T. A review of the clinical performance of the Aptima HPV assay. J Clin Virol. 2016;76 Suppl 1:S40-8.

41. Reid JL, Wright TC Jr, Stoler MH, et al. Human papillomavirus oncogenic mRNA testing for cervical cancer screening: baseline and longitudinal results from the CLEAR study. Am J Clin Pathol. 2015;144(3):473-83.

42. Ting J, Smith JS, Myers ER. Cost-Effectiveness of High-Risk Human Papillomavirus Testing With Messenger RNA Versus DNA Under United States Guidelines for Cervical Cancer Screening. J Low Genit Tract Dis. 2015;19(4):333-9.

43. Felix JC, Lacey MJ, Miller JD, et al. The Clinical and Economic Benefits of Co-Testing Versus Primary HPV Testing for Cervical Cancer Screening: A Modeling Analysis. J Womens Health (Larchmt). 2016;25(6):606-16.

44. Weston G, Dombrowski C, Harvey MJ, et al. Use of the Aptima mRNA high-risk human papillomavirus (HR-HPV) assay compared to a DNA HR-HPV assay in the English cervical screening programme: a decision tree model based economic evaluation. BMJ Open. 2020;10(3):e031303.

45. Tewari P, White C, Kelly L, et al. Clinical performance of the Cobas 4800 HPV test and the Aptima HPV assay in the management of women referred to colposcopy with minor cytological abnormalities. Diagn Cytopathol. 2018;46(12):987-992.

46. de Sanjosé S, Ibáñez R, Rodríguez-Salés V, et al. El cribado del cáncer de cuello de útero en el Sistema Público de Salud de Cataluña. Evaluación y seguimiento durante el periodo 2006-2012. Prog Obstet Ginecol. 2015;58:209-20.

\section{Tables}

\section{Table 1. Model inputs}




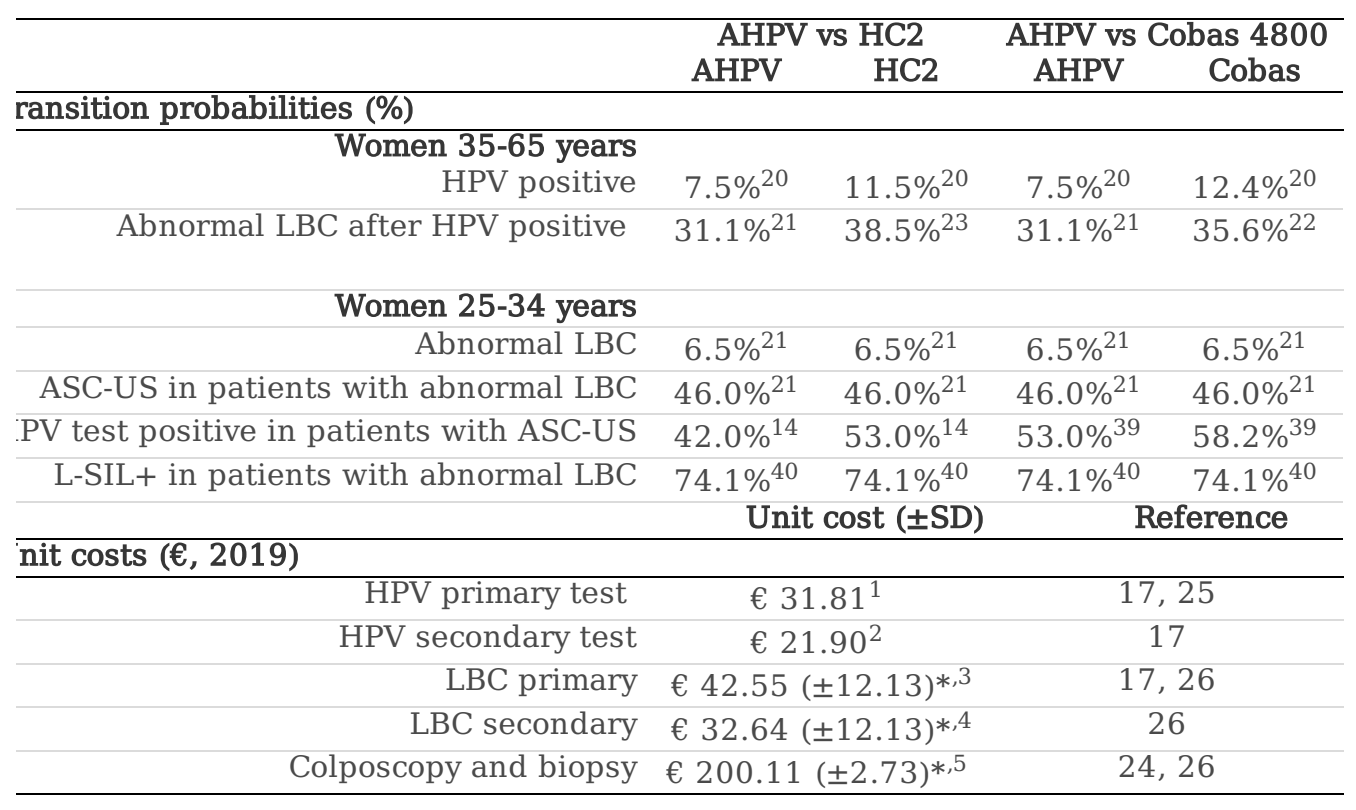

*Average cost obtained from the list of references identified in the Spanish database. 1. Includes sample-taking costs (human resources, disposables and vial), costs of molecular detection of HPV processing and interpretation of results; 2. Includes costs of molecular detection of HPV processing and interpretation of results; 3. Includes sample-taking costs (human resources, disposables and vial), costs of cytology processing and interpretation; 4. Includes costs of cytology processing and interpretation; 5. Includes the colposcopy procedure with processing and interpretation of one biopsy.

ASC-US+: any cytology result from atypical squamous cells of undetermined significance to carcinoma; AHPV: Aptima HPV Assay; HC2: Hybrid Capture 2 Assay; HPV: human papilloma virus; LBC: liquid-base cytology; L-SIL+: any cytology result from low-grade squamous intraepithelial lesions to carcinoma; SD: Standard deviation.

\section{Table 2. Base-case and sensitivity analysis results}


SE-CASE RESULTS (women aged 35-65 years. $\mathrm{N}=7,263,529$

men)

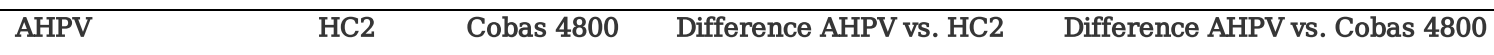

mber of procedures performed according to HPV detection technology and assuming cervical cancer screening coverage of $70 \%$

\begin{tabular}{rccccc}
\hline HPV & $7,263,529$ & $7,263,529$ & $7,263,529$ & 0 & 0 \\
LBC & 544,765 & 835,306 & 900,678 & $-290,541(-35 \%)$ & $-355,913(-40 \%)$ \\
\hline Colposcopies & 169,476 & 321,175 & 320,641 & $-151,699(-47 \%)$ & $-151,165(-47 \%)$
\end{tabular}

st of performing the different procedures

\begin{tabular}{|c|c|c|c|c|c|}
\hline HPV test cost & $€ 231,052,857$ & $\begin{array}{c}€ \\
231,052,857\end{array}$ & $\begin{array}{c}€ \\
231,052,857\end{array}$ & - & - \\
\hline LBC cost & $€ 17,781,199$ & $€ 27,264,382$ & $\begin{array}{c}€ \\
29,398,177\end{array}$ & $€-9,483,263$ & $€-11,616,998$ \\
\hline $\begin{array}{r}\text { Colposcopy and } \\
\text { biopsy cost }\end{array}$ & $€ 33,931,900$ & $€ 64,270,348$ & $\begin{array}{c}€ \\
64,163,515\end{array}$ & $€-30,356,448$ & $€-30,249,615$ \\
\hline Total cost & $€ 282,747,877$ & $\begin{array}{c}€ \\
322,587,588\end{array}$ & $\begin{array}{c}€ \\
324,614,490\end{array}$ & $€-39,839,711$ & $€-41,866,613$ \\
\hline
\end{tabular}

NSITIVITY ANALYSIS RESULTS

\begin{tabular}{|c|c|c|c|c|c|c|c|c|}
\hline & & \multirow[b]{2}{*}{ Base-case value } & \multirow[b]{2}{*}{ SA value } & \multicolumn{5}{|c|}{ Cost form entry in screening until first colposcopy was performed } \\
\hline & & & & AHPV & HC2 & Cobas 4800 & $\begin{array}{l}\text { Difference } \\
\text { AHPV vs. } \\
\text { HC2 }\end{array}$ & $\begin{array}{c}\text { Difference } \\
\text { AHPV vs. } \\
\text { Cobas } \\
4800 \\
\end{array}$ \\
\hline \multicolumn{2}{|c|}{$\begin{array}{l}\text { get population } \\
.3 \% \text { coverage in } \\
\text { rate service) }\end{array}$} & $\begin{array}{c}\text { 7,263,529 women } \\
\text { (Assuming a } \\
\text { cervical cancer } \\
\text { screening coverage } \\
\text { of } 70 \% \text { ) }\end{array}$ & $\begin{array}{c}\text { 4,626,868 women } \\
\text { (Assuming a cervical } \\
\text { cancer screening } \\
\text { coverage of } 44.6 \% \text { ) }\end{array}$ & $€ 180,110,398$ & $€ 205,488,294$ & $€ 206,779,430$ & $\begin{array}{c}€ \\
-25,377,896\end{array}$ & $\begin{array}{c}€ \\
-26,669,032\end{array}$ \\
\hline \multirow{4}{*}{$\begin{array}{l}\text { nsition } \\
\text { babilities } \\
\text { गV } \\
\text { itive) }\end{array}$} & \multirow[t]{2}{*}{$\begin{array}{c}\text { AHPV } \\
\text { vs. HC2 }\end{array}$} & \multirow[t]{2}{*}{$\begin{array}{l}\text { AHPV: } 7.5 \% \\
\text { HC2: } 11.5 \%\end{array}$} & $\begin{array}{l}\text { AHPV: } 10.3 \%^{13} \\
\text { HC2: } 15.7 \%^{13}\end{array}$ & $€ 302,047,351$ & $€ 356,017,663$ & \multicolumn{3}{|c|}{$-53,970,312$} \\
\hline & & & $\begin{array}{l}\text { AHPV: } 7.2 \%^{29} \\
\text { HC2: } 8.4 \%{ }^{29}\end{array}$ & $€ 280,680,076$ & $€ 297,913,008$ & \multicolumn{3}{|c|}{$-17,232,932$} \\
\hline & \multirow{2}{*}{$\begin{array}{l}\text { AHPV } \\
\text { vs. } \\
\text { Cobas } \\
4800\end{array}$} & \multirow[t]{2}{*}{$\begin{array}{c}\text { AHPV: } 7.5 \% \\
\text { Cobas: } 12.4 \%\end{array}$} & $\begin{array}{l}\text { AHPV: } 15.3 \%^{12} \\
\text { Cobas: } 24.4 \%^{12}\end{array}$ & $€ 336,510,697$ & - & $€ 415,158,005$ & - & $\begin{array}{c}€ \\
-78,647,307 \\
\end{array}$ \\
\hline & & & $\begin{array}{l}\text { AHPV: } 12.8 \%^{30} \\
\text { Cobas } 14.6 \%^{30}\end{array}$ & $€ 319,279,024$ & - & $€ 341,214,134$ & - & $\begin{array}{c}€ \\
-21,935,110\end{array}$ \\
\hline \multirow{2}{*}{\multicolumn{2}{|c|}{$\begin{array}{l}\text { G, colposcopy and } \\
\text { psy costs }\end{array}$}} & \multirow{2}{*}{$\begin{array}{c}\text { Primary LBC: } \\
€ 42.55 \\
\text { Colposcopy+biopsy: } \\
€ 200.11\end{array}$} & $\begin{array}{c}\text { LBC: } € 50.56^{31} \\
\text { Colposcopy+biopsy: } \\
€ 249.99^{31}\end{array}$ & $€ 295,564,919$ & $€ 345,298,601$ & $€ 347,822,501$ & $\begin{array}{c}€ \\
-49,733,682\end{array}$ & $\begin{array}{c}€ \\
-52,257,582\end{array}$ \\
\hline & & & $\begin{array}{c}\text { LBC: } € 18.31^{17} \\
\text { Colposcopy+biopsy: } \\
€ 134.64^{17}\end{array}$ & $€ 258,447,168$ & $€ 281,312,441$ & $€ 281,789,684$ & $\begin{array}{c}€ \\
-22,865,273\end{array}$ & $\begin{array}{c}€ \\
-23,342,515\end{array}$ \\
\hline
\end{tabular}

AHPV: Aptima HPV Assay; HC2: Hybrid Capture 2 Assay; HPV: human papilloma virus; LBC: liquid-base cytology.

\section{Figures}



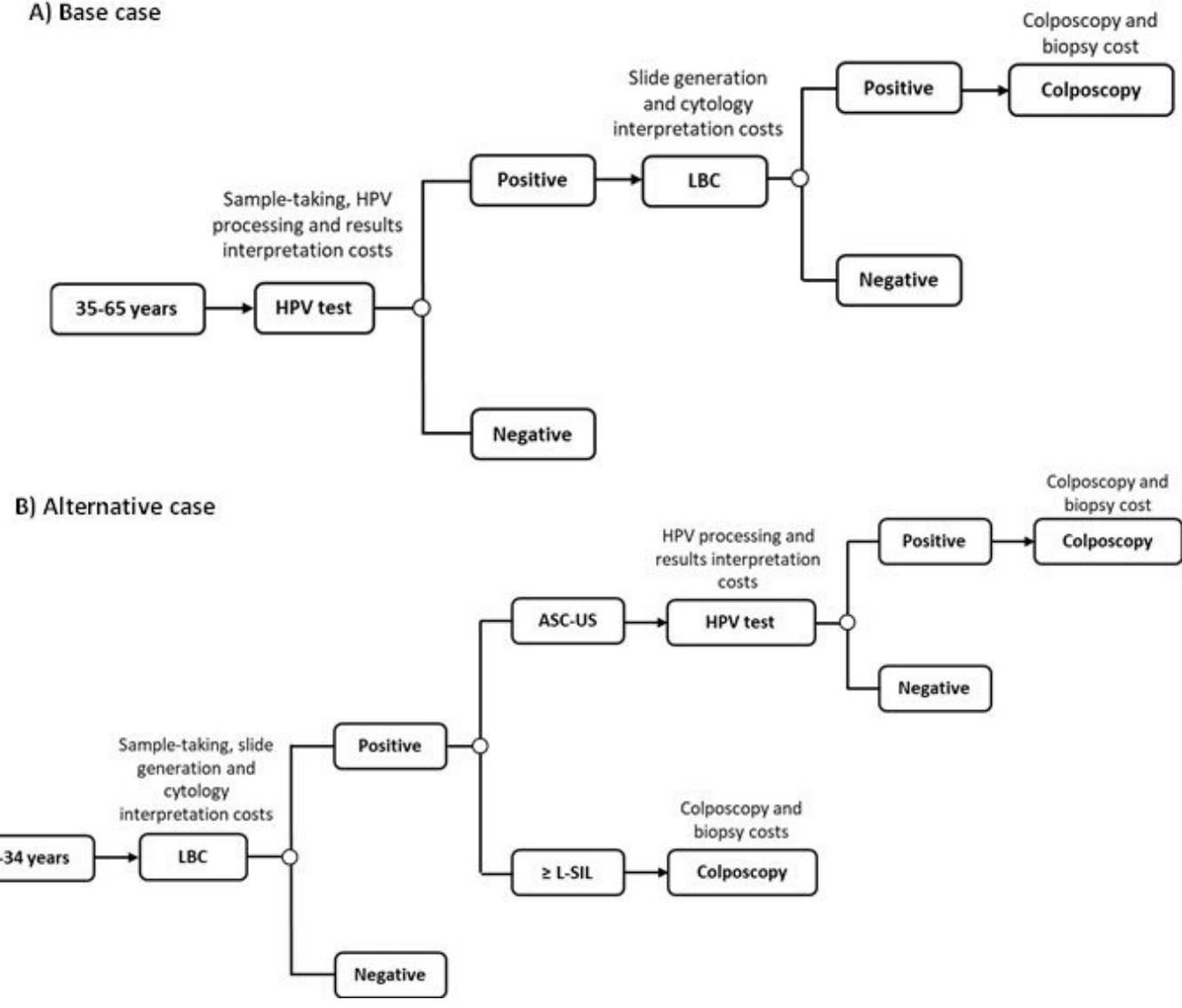

Figure 1

Decision tree model and procedures included
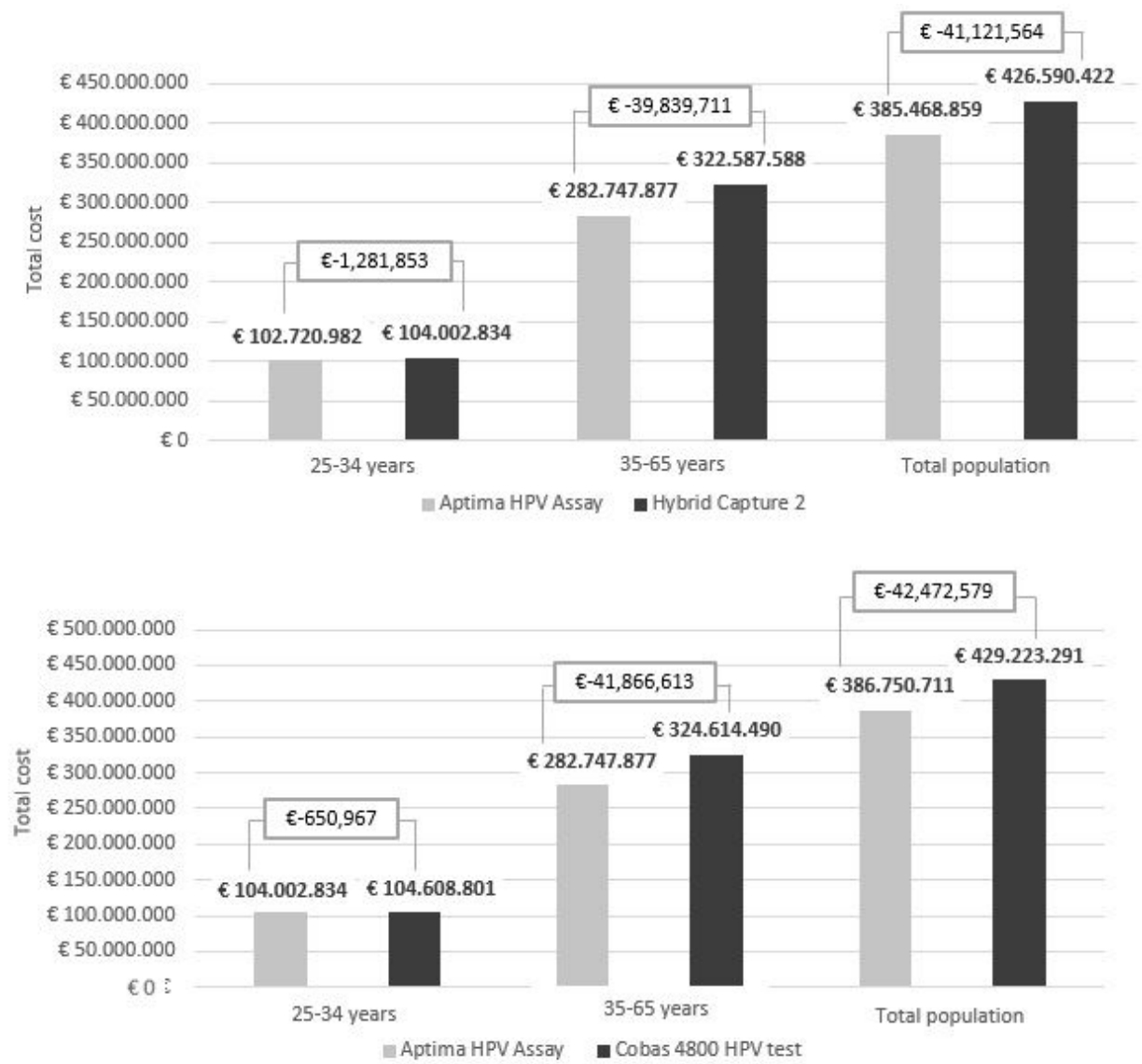


\section{Figure 2}

Total cost of cervical cancer screening programme from inclusion to the first colposcopy by age groups

\section{Supplementary Files}

This is a list of supplementary files associated with this preprint. Click to download.

- Supplementarymaterial.docx 